\title{
EXPLORATION OF ANTI-HYPERGLYCEMIC AND HYPOLIPIDEMIC ACTIVITIES OF ETHANOLIC EXTRACT OF TINOSPORA CARDIFOLIA (WILLD)HOOK WHOLE PLANT IN ALLOXAN INDUCED DIABETIC RATS
}

\author{
T. Naga Ravikiran ${ }^{* 1}$, A.V.S. Madhulatha ${ }^{2}$, D. Lohithasu ${ }^{3}$, Y. Rajendra Prasad ${ }^{1}$
}

${ }^{1}$ Department of Pharmaceutical chemistry, A U college of Pharmaceutical Sciences, Andhra University, Visakhapatnam, India

${ }^{2}$ Dept of pharmaceutics, Krishna university, Visakhapatnam, India

${ }^{3}$ Dept of pharmaceutics, Gitam University, Visakhapatnam, India

Received 07 Feb 2015; Review Completed 14 March 2015; Accepted 14 March 2015, Available online 15 March 2015

\begin{abstract}
Natural remedies from medicinal plants are considered to be effective and safe alternative treatment for diabetes mellitus. The aim of present study was to demonstrate the hypoglycemic and anti-diabetic activity of the ethanolic extract of Tinospora cardifolia (willd)Hook whole plant in alloxan induced diabetic animals with a view to explore its use for the treatment of diabetes mellitus in humans. The ethanolic extract of Tinospora cardifolia whole plant was investigated for its antihyperglycemic and anti-hyperlipidemic effects in male albino rats. Diabetes was induced in the albino rats by administration of a single dose of alloxan monohydrate $(150 \mathrm{mg} / \mathrm{kg}$, bwt, i.p) and the ethanolic extract of Tinospora cardifolia whole plant was administered daily at single doses of 100 and $200 \mathrm{mg} / \mathrm{kg}$, p. o to diabetes induced rats for a period of 14 days. The effect of ethanolic extract of Tinospora cardifolia whole plant on blood glucose level was measured in the diabetic rats. Serum lipid profiles [total cholesterol, triglycerides, phospholipids (low density, very low density and high density lipoprotein)] were also determined. The activities were also compared to the activity produced by a standard anti diabetic agent, Glibenclamide ( 500 $\mu \mathrm{g} / \mathrm{kg}$ ). The present investigation established pharmacological evidence to support the folklore claim that ethanolic extract of Tinospora cardifolia whole plant is an anti-diabetic agent.
\end{abstract}

Keywords: Diabetes, Tinospora cardifolia, Alloxan, HDL,VLDL and fasting blood glucose

\section{INTRODUCTION}

Diabetes mellitus is a metabolic syndrome, initially characterized by a loss of glucose homeostasis resulting from defects in insulin secretion, insulin action both resulting in impaired glucose metabolism and other energy-yielding fuels such as lipids and protein 1. Dyslipidemia is a frequent complication of DM and is characterized by low levels of high density lipoprotein cholesterol (HDL-C) and high levels of low density lipoprotein-cholesterol (LDLC) and triglyceride (TG). Several groups of hypoglycemic drugs are currently available to treat DM ${ }^{2}$. Different types of oral hypoglycemic agents such as biguanides and sulphonylureas are available along with insulin for the treatment of diabetes mellitus, but have side effects associated with their uses ${ }^{3}$. There is a growing interest in herbal remedies because of their effectiveness, minimal side effects in clinical experience and relatively low costs.

Tinospora cordifolia (Willd.) Miers ex Hook. F. and Thoms belonging to the family Menispermaceae, is a large, deciduous, climbing shrub found throughout
India, especially in the tropical parts ascending to an altitude of $300 \mathrm{~m}$. and also in certain parts of China ${ }^{4}$. It is known as heart leaved Moonseed plant in English, Guduchi in Sanskrit and Giloy in Hindi.

Guduchi is widely used in veterinary folk medicine ayurvedic system of medicine for its general tonic, antiperiodic, anti-spasmodic, anti-inflammatory, antiarthritic, anti-allergic and anti-diabetic properties ${ }^{5-9}$. The plant is used in ayurvedic, "Rasayanas" to improve the immune system and the body resistance against infections. The root of this plant is known for its antistress, anti-leprotic and anti-malarial activities 10-11. Authors investigated earlier one of the plants of the family Menispermaceae and found that the constituents and activities were similar to other reports ${ }^{\mathbf{1 2}-13}$.

*Corresponding Author T. Naga Ravikiran

T. Naga Ravikiran* Research scholar, Dept. of Pharmaceutical chemistry, Andhra University, Visakhapatnam, India Email: ravikirannaga58@gmail.com 


\section{MATERIALS AND METHODS}

\section{Plant materials}

The whole plant Tinospora cardifolia(willd)Hook. F. \&Th. was collected in perecherla, Guntur district and authentified by Dr. S. M. Khasim, Dept. of Botany, Acharya Nagarjuna University, Guntur, Andhra Pradesh and a voucher specimen was kept in that department.

\section{Drugs and chemicals}

Alloxan monohydrate was procured from LOBA CHEMIE laboratory reagents and fine chemicals, Mumbai. Glibenclamide was gifted sample from TABLETS INDIA PVT LTD; Mumbai. Enzymatic kits for the estimation of lipid profile were obtained from CHEMA DIAGNOSTICA (INDIA).

\section{Preparation of plant extract}

The stems of Tinospora Cardifolia were collected in bulk, washed with running tap water to remove the adhering impurities, dried in shade for40 days, powdered using a mechanical pulverizer, sifted and the prepared powder was then extracted using ethanol with the help of Soxhlet extractor(hot and continuous percolation). the product obtained was filtered and evaporated under reduced pressure to get the alcoholic crude extract and it was then stored in the refrigerator for further use.

\section{Experimental Animals ${ }^{14}$}

This study was carried out in healthy, male young adult, Adult wister rats belonging to both the sex were purchased from the animal house of Mahaveera Enterprises, Hyderabad(146/1999/CPCSEA). After randomization into various groups and before initiation of experiment the rats were acclimatized for a period of 7 days under standard environmental conditions of temperature, relative humidity, and dark/light cycle. Animals described as fasting were deprived of food and water for 16 hours ad libitum.

\section{Experimental Protocol}

\section{Acute study in normal rats}

Animals were divided into 4 groups of 3 rats each.

Group I: Rats served as normal-control and received the vehicle $(0.5 \mathrm{ml}$ distilled water/day/rat)

Group II: Rats (normal) were administered ethanolic extract of Tinospora cardifolia whole plant $(100 \mathrm{mg} / \mathrm{kg}$ b. wt. /day) in distilled water as a fine aqueous suspension orally.

Group III: Rats (normal) were administered ethanolic extract of Tinospora cardifolia whole plant $(200 \mathrm{mg} / \mathrm{kg}$ b. wt. /day) in distilled water as a fine aqueous suspension orally.

Group IV: Rats (normal) were administered Glibenclamide $(500 \mu \mathrm{g} / \mathrm{kg}$ b. wt. /day) in distilled water as a fine aqueous suspension orally.

Blood samples were collected by tail vein puncture just prior to drug administration i. e. at $0 \mathrm{hr}$ and at 1, 2, 4, and $6 \mathrm{hrs}$. The blood glucose was estimated by Accu check glucometer ${ }^{15}$.

\section{Acute study in diabetic rats}

Animals were divided into 4 groups of 3 rats each.

Group I: Rats served as normal-control and received the vehicle $(0.5 \mathrm{ml}$ distilled water/day/rat)

Group II: Rats (normal) were administered ethanolic extract of Tinospora cardifolia whole plant (100 $\mathrm{mg} / \mathrm{kg} \mathrm{b}$. wt. /day) in distilled water as a fine aqueous suspension orally.

Group III: Rats (normal) were administered ethanolic extract of of Tinospora cardifolia whole plant (200 $\mathrm{mg} / \mathrm{kg} \mathrm{b}$. wt. /day) in distilled water as a fine aqueous suspension orally.

Group IV: Rats (normal) were administered Glibenclamide $(500 \mu \mathrm{g} / \mathrm{kg}$ b. wt. /day) in distilled water as a fine aqueous suspension orally.

\section{Induction of Diabetes in Experimental Animals:}

Rats were fasted for 16 hours and were induced with alloxan monohydrate, $150 \mathrm{mg} / \mathrm{kg}$ body weights (bwt), intraperitoneally (ip) ${ }^{16}$. Hyperglycaemia was confirmed when elevated blood glucose level was $\geq 200 \mathrm{mg}$. $\mathrm{dL}^{-1}$ after 72 hours of injection 10 .

\section{Blood sugar estimation on diabetic rats}

The diabetic animals were randomized to the following groups of 3 rats each: group I served as diabetic control, groups II and III received graded doses of the extract at 100 , and $200 \mathrm{mg}$. $\mathrm{kg}^{-1}$ bwt respectively by gavages. Group IV received glibenclamide $\left(500 \mu \mathrm{g} . \mathrm{kg}^{-1} \mathrm{bwt}\right)$. Blood samples were collected by tail vein puncture just prior to drug administration i. e. at $0 \mathrm{hr}$ and at $1,2,4$, and $6 \mathrm{hrs}$. The blood glucose was estimated by Accu check glucometer ${ }^{17}$.

\section{Chronic study in diabetic rats}

Animals were divided into 4 groups of 3 rats each.

Group I: Rats served as normal-control and received the vehicle $(0.5 \mathrm{ml}$ distilled water/day/rat)

Group II: Rats (normal) were administered ethanolic extract of Tinospora cardifolia whole plant (100 $\mathrm{mg} / \mathrm{kg} \mathrm{b}$. wt. /day) in distilled water as a fine aqueous suspension orally.

Group III: Rats (normal) were administered ethanolic extract of Tinospora cardifolia whole plant $(200 \mathrm{mg} / \mathrm{kg}$ b. wt. /day) in distilled water as a fine aqueous suspension orally.

Group IV: Rats (normal) were administered Glibenclamide $(500 \mu \mathrm{g} / \mathrm{kg}$ b. wt. /day) in distilled water as a fine aqueous suspension orally.

All the rats were fasted for $16 \mathrm{hr}$. Before experimentation, but allowed free access to water.

Chronic Study ${ }^{18}$ : All the rats received treatment for 14 days in all groups. 


\section{Collection of Blood Sample and Blood Glucose Determination:}

The diabetic animals were randomized to the following groups of 3 rats each: group I served as normal while group II was diabetic control, groups III and IV received graded doses of the extract at 100 , and $200 \mathrm{mg}$. $\mathrm{kg}^{-1}$ b. wt respectively by gavages. Group $\mathrm{V}$ received

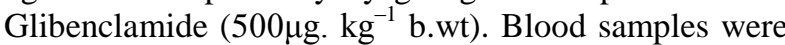
drawn from tail tip of rat at weekly intervals till the end of study (i. e., 2 weeks). Fasting blood glucose estimation and body weight measurement were done on day 0,7 , and 14 of the study. Blood glucose estimation can be done by Accu check glucometer using glucose test strips. The results were expressed in terms of $\mathrm{mg} / \mathrm{dl}$ of blood.

Percentage change in body weight $=$

[Weight initial: measurement on the first day (D0);

Weight n: measurements at end of D2, D4... D14] ${ }^{19}$

\section{Estimation of biochemical parameters}

On day 14 , Serum cholesterol ${ }^{20}$ and triglycerides ${ }^{21}$ were estimated on final day of experiment of each model by CHOD -POD method and enzymatic colorimetric method (GPO which is highly influenced by level of fasting). $\mathrm{HDL}^{22}$ cholesterol was determined by using $\operatorname{LDLC}^{23}$ was derived from cholesterol and triglycerides values, VLDL cholesterol value was derived from cholesterol and triglycerides value was derived from cholesterol and HDL values.

\section{Statistical analysis}

All values were expressed as mean \pm standard error of mean and the statistical significance between treated and control groups were analyzed by means of Student's ttest. $\mathrm{P}<0.05$ was considered significant.

\section{RESULTS}

\section{Acute study}

\section{Effect of Ethanolic TCWE on fasting blood glucose in normal rats}

The results of effect of oral administration of the plant extract on normal rats were shown in Table 1.100 $\mathrm{mg} / \mathrm{kg}$ b.wt dose of ethanolic extract of Tinospora cardifolia did not cause any significant change in blood sugar levels. But $200 \mathrm{mg} / \mathrm{kg}$ b. wt dose of ethanolic extract of Tinospora cardifolia shows significant change in blood sugar levels.
2. Effect of Ethanolic ambe on fasting blood glucose in alloxan induced diabetic rats

The results of effect oral administration of the plant extract on diabetic rats were shown in Table 2.100 and $200 \mathrm{mg} / \mathrm{kg} \mathrm{b}$. wt dose of ethanolic extract of Tinospora cardifolia exhibited significant change in blood sugar levels.

\section{Chronic study}

\section{Effect on Body weight}

Animals exhibited decrease in appetite and weight depreciation after alloxan induction. In the untreated group, progressive weight decrease occurred while in the extract Glibenclamide treated, there was weight appreciation after few days of treatment as well as showed increase in appetite.

\section{Effect on Fasting Blood Glucose (FBG) Levels}

The Table 3 and figure 4 demonstrate the levels of FBG in alloxan induced diabetic rats. The administration of both doses of ethanolic extract of Tinospora cardifolia to diabetic rats resulted in a significant decrease in the levels of fasting blood glucose. In ethanolic extract of Tinospora cardifolia treated rats, although a significant antihyperglycemic effect was evident from the 7 day onwards; the decrease in FBG was highly pronounced on 15 day and moved towards resettlement to the normal level.

\section{Effect of ethanolic extract of of Tinospora cardifolia} on the Serum Lipid Profile

Tables 4 illustrate the effects of ethanolic extract of of Tinospora cardifolia on the levels of total cholesterol, triglycerides, HDLC, LDLC, VLDLC in the serum of experimentally induced diabetic rats. The levels of total cholesterol, triglycerides LDL-C and VLDL-C were significantly $(\mathrm{p}<0.05)$ increased in diabetic rats whereas the level of HDL-C were significantly $(\mathrm{p}<0$. 05) reduced in diabetic rats when compared to the control normal rats. Administration of ethanolic extract of Tinospora cardifolia to ALLOXAN induced diabetic rats restored all these changes to near normal levels by significant $(\mathrm{p}<0.05)$ reduction of the level of total cholesterol, triglycerides, LDLC and VLDLC of diabetic rats and significant increase in the level of HDL-C. 
Table 1: Variation in blood glucose levels after oral administration of ethanolic extract of Tinospora cardifolia whole plant in normal rats in acute study

\begin{tabular}{|l|l|l|l|l|l|l|}
\hline \multicolumn{2}{|c|}{} & \multicolumn{5}{c|}{ BLOOD(SERUM) GLUCOSE CONCENTRAION(mg/ml) } \\
\hline GROUP & $\begin{array}{l}\text { TREATMENT } \\
\mathrm{mg} / \mathrm{kg}\end{array}$ & $\begin{array}{l}\text { Ohr } \\
(\mathrm{mg} / \mathrm{dl})\end{array}$ & $\begin{array}{l}1 \mathrm{hr} \\
(\mathrm{mg} / \mathrm{dl})\end{array}$ & $\begin{array}{l}2 \mathrm{hr} \\
(\mathrm{mg} / \mathrm{dl})\end{array}$ & $\begin{array}{l}3 \mathrm{hr} \\
(\mathrm{mg} / \mathrm{dl})\end{array}$ & $\begin{array}{l}6 \mathrm{hr} \\
(\mathrm{mg} / \mathrm{dl})\end{array}$ \\
\hline 1. & Normal (control) & $93.0 \pm 1.6$ & $92 \pm 1.5$ & $90.6 \pm 1.2$ & $88.7 \pm 1.2$ & $83.3 \pm 1.26$ \\
\hline 2. & $\begin{array}{l}\text { TCWE }(100 \mathrm{mg} / \mathrm{kg} \\
\text { b.w) }\end{array}$ & $92 \pm 11.0$ & $86 \pm 8.5$ & $82.5 \pm 180 \pm$ & $80 \pm 8.2^{* *}$ & $88 \pm 2.0$ \\
\hline 3. & $\begin{array}{l}\text { TCWEE } \\
\text { mg/kg b.w) }\end{array}$ & $91 \pm 6.0$ & $76 \pm 2.0^{*}$ & $52.6 \pm 8.5^{* *}$ & $50 \pm 7.2^{* * *}$ & $61.5 \pm 6$ \\
\hline 4. & $\begin{array}{l}\text { Glibenclamide } \\
(500 \mu \mathrm{\mu g} / \mathrm{kg})\end{array}$ & $93 \pm 1.2$ & $86 \pm 2.7$ & $72 \pm 7.6^{*}$ & $60 \pm 7.8^{* *}$ & $54 \pm 8.2^{* * * *}$ \\
\hline
\end{tabular}

Table 2: Variation in blood glucose levels after oral administration of ethanolic extract of Tinospora cardifolia whole plant in alloxan induced diabetic rats in acute study.

\begin{tabular}{|l|l|l|l|l|l|l|}
\hline & \multicolumn{5}{|l|}{ BLOOD(SERUM)GLUCOSE CONCENTRAION(mg/ml) } \\
\hline GROUP & TREATMENT & $\begin{array}{l}\text { Ohr } \\
(\mathrm{mg} / \mathrm{dl})\end{array}$ & $\begin{array}{l}1 \mathrm{hr} \\
(\mathrm{mg} / \mathrm{dl})\end{array}$ & $\begin{array}{l}2 \mathrm{hr} \\
(\mathrm{mg} / \mathrm{dl})\end{array}$ & $\begin{array}{l}3 \mathrm{hr} \\
(\mathrm{mg} / \mathrm{dl})\end{array}$ & $\begin{array}{l}6 \mathrm{hr} \\
(\mathrm{mg} / \mathrm{dl})\end{array}$ \\
\hline 1. & Normal (control) & $86.24 \pm 2.76$ & $272.22 \pm 3.21$ & $225.62 \pm 4.21$ & $182.16 \pm 2.36$ & $122.40 \pm 3.14$ \\
\hline 2. & $\begin{array}{l}\text { Glibenclamide }(500 \\
\mu / \mathrm{kg})\end{array}$ & $92.41 \pm 3.81$ & $141.46 \pm 7.2$ & $132.46 \pm 1.16$ & $110.29 \pm 5.45$ & $101.66 \pm 2.36$ \\
\hline 3. & $\begin{array}{l}\text { TCWE (100 } \mathrm{mg} / \mathrm{kg} \\
\text { b.w) }\end{array}$ & $87.37 \pm 4.42$ & $202.33 \pm 5.67$ & $154.49 \pm 8.12$ & $128.62 \pm 4.46$ & $110.24 \pm 5.46$ \\
\hline 4. & $\begin{array}{l}\text { TCWEE }(200 \mathrm{mg} / \mathrm{kg} \\
\text { b.w) }\end{array}$ & $82.55 \pm 3.86$ & $168.76 \pm 9.32$ & $143.52 \pm 9.16$ & $113.79 \pm 7.21$ & $104.31 \pm 6.23$ \\
\hline
\end{tabular}

Table 3: Effects of ethanolic extract of Tinospora cardifolia whole plant on Fasting blood glucose (FBG) in alloxan induced diabetic rats in chronic study.

\begin{tabular}{|l|l|l|l|l|}
\hline \multirow{2}{*}{ GROUP } & \multirow{2}{*}{ Treatment $(\mathbf{m g} / \mathbf{k g})$} & \multicolumn{3}{|l|}{ BLOOD(SERUM) GLUCOSE CONCENTRAION(mg/ml) } \\
\cline { 3 - 5 } & & Initial day & 7th day & 14th day \\
\hline $\mathbf{1 .}$ & Normal (control) & $74.00 \pm 1.00$ & $83.33 \pm 4.16$ & $81.00 \pm 1.00$ \\
\hline $\mathbf{2 .}$ & Diabetic (control) & $315.00 \pm 5.00$ & $339.00 \pm 9.00$ & $362.33 \pm 5.69$ \\
\hline $\mathbf{3 .}$ & TCWE $(100 \mathrm{mg} / \mathrm{kg}$ b.w) & $315.33 \pm 3.51$ & $283.33 \pm 5.13$ & $210.33 \pm 4.51$ \\
\hline $\mathbf{4 .}$ & TCWE $(200 \mathrm{mg} / \mathrm{kg}$ b.w) & $312.67 \pm 2.52$ & $249.0 \pm 7.57$ & $187.33 \pm 6.43$ \\
\hline $\mathbf{5 .}$ & Glibenclamide $(500 \mu \mathrm{g} / \mathrm{kg})$ & $309.33 \pm 3$ & $213.00 \pm 3.61$ & $148.0 \pm 1.0$ \\
\hline
\end{tabular}

Table 4: Effect of ethanolic extract of Tinospora cardifolia whole plant on biochemical profiles of the control and treated animals in the chronic study.

\begin{tabular}{|c|c|c|c|}
\hline & $\begin{array}{c}\text { Total } \\
\text { Cholesterol }\end{array}$ & Triglycerides & HDL \\
\hline & Mean \pm SEM & Mean \pm SEM & Mean \pm SEM \\
\hline Normal Control & $52.33 \pm 2.52$ & $46.33 \pm 1.53$ & $74.33 \pm 2.08$ \\
\hline Diabetic Control & $115.33 \pm 2.52$ & $135.67 \pm 4.04$ & $30.67 \pm 4.04$ \\
\hline Diabetic+TCWE $(100 \mathrm{mg} / \mathrm{kg})$ & $95.00 \pm 4.58$ & $85.67 \pm 4.93$ & $58.33 \pm 2.08$ \\
\hline Diabetic+TCWE(200mg/kg) & $89.00 \pm 1.00$ & $75.67 \pm 4.04$ & $65.67 \pm 4.04$ \\
\hline $\begin{array}{c}\text { Diabetic+Glibenclamide } \\
(500 \mu \mathrm{\mu g} / \mathrm{kg})\end{array}$ & $89.00 \pm 3.61$ & $71.67 \pm 3.51$ & $71.67 \pm 3.50$ \\
\hline
\end{tabular}




\section{DISCUSSION}

Medicinal plants have been used for centuries in the treatment of diabetes mellitus. The need to evaluate the toxicity profile of ethanolic extract of of Tinospora cardifolia was prompted by the increasing awareness and interest in medicinal plants and their preparations commonly known as herbal medicine. In oral acute toxicity studies, no untoward clinical signs were observed in the rats. The extract was safe up to a dose of $6000 \mathrm{mg} / \mathrm{kg}^{23}$.

In oral acute studies, no untoward clinical signs were observed in the rats at two doses studied (100 and 200 $\mathrm{mg} / \mathrm{kg}$ ). There were no changes in the nature of stool, urine and eye colour. No mortality was observed at two dose levels from the critical 24 hours post administration to the end of the fourteen day.

In chronic studies, all rats used for the study appeared normal before, during and post-treatment. Mortality was not recorded at two dose levels used for the study; 100 , and $200 \mathrm{mg} / \mathrm{kg} \mathrm{b}$. wt.

The result of this present study clearly shows that ethanolic extract of of Tinospora cardifolia has a lipid lowering effects on serum triglycerides, total cholesterol cholesterol of Alloxan induced diabetic rats. ethanolic extract of Tinospora cardifolia treatment also increase the serum level of High-density lipoprotein cholesterol termed as "good cholesterol". There is a substantial evidence that lowering the total cholesterol, particularly LDL-C level will lead to a reduction in the incidence of coronary heart disease which is still the leading cause of death in diabetic patients.

As there is a close relationship between elevated serums total cholesterol level and occurrence of atherosclerosis, the ability of the ethanolic extract of of Tinospora

\section{REFERRENCES}

1. El-Soud NHA, Khalil MY, Hussein JS, Oraby FSH, Farrag FAR. Anti-diabetic effects of fenugreek alkaliod extract in streptozotocin induced hyperglycemic rats. J Appl Sci Res, 3, 2007, 1073-1083.

2. D. O. Adeyemi, O. A. Komolafe, S. O. Adewole, E. M. Obuotor: Anti Hyperlipidemic Activities of Annona Muricata (Linn). The Internet Journal of Alternative Medicine. 7(1), 2009, DOI: 10. 5580/293b.

3. Rajesh Kumar Gupta, Achyut Narayan Kesari, Geeta Watal, P. S. Murthy, Ramesh Chandra, Kapil Maithal and Vibha Tandon, Hypoglycaemic and antidiabetic effect of aqueous extract of leaves of Annona squamosa (L.) in experimental animal, CURRENT SCIENCE, 88, 25 APRIL 2005, 1244.

4. Anonymous. Wealth of India: Raw materials. CSIR, New Delhi, 1976, 10.

5. Chopra RN, Chopra LC, Handa KD, Kapur LD, editors. Indigenous Drugs of India. 2nd ed. Kolkata: M/S Dhar VN \& Sons; 1982.

6. Zhao TF, Wang X, Rimando AM, Che C. Folkloric medicinal plants: Tinospora sagittata var. cravaniana and Mahonia bealei. Planta Med 1991;57:505.

7. Nayampalli S, Ainapure SS, Nadkarni PM. Study of antiallergic acid Bronchodilator effects of Tinospora cordifolia. Indian J Pharm 1982;14:64-6. cardifolia in the selective reduction of total cholesterol through the reduction of LDL and VLDL components could be beneficial in preventing atherosclerotic conditions and thereby reduce the possibilities of coronary heart disease in general. Considering the effect of extract of ethanolic extract of Tinospora cardifolia on serum HDL, the result of this study clearly show that the level of this lipoprotein fraction increased with this treatment. Some phytochemical compounds such as alkaloids, diterpenoid lactones, glycosides, steroids, sesquiterpenoid, phenolics, aliphatic compounds and polysaccharides have been implicated in the antidiabetic activities of plants ${ }^{24}$.

\section{CONCLUSION}

The ever-increasing onset of side effects associated with the synthetic drugs lead to the search of a viable substitute especially from natural (flora and fauna) origin.

Through present work, ethanolic extract of Tinospora cardifolia whole plant seems to be useful in controlling elevated blood glucose levels in diabetes induced by alloxan in rats and also lowers hyper triglyceridemia and hypercholesterolemia in alloxan induced diabetic rats. These results indicate that it is worth undertaking further studies on possible usefulness of the ethanolic extract of Tinospora cardifolia in diabetes mellitus.

\section{CONFLICT OF INTEREST STATEMENT}

We, the authors of the article find and declare no points of conflict of interest.

\section{ACKNOWLEDGEMENTS}

We, the authors of this article are grateful to K. Kishore Naidu and D.M. Kumar for their constructive support during the completion of the work.

8. Agarwal SK, Singh SS, Verma S, Kumar S. Two picrotoxin derivatives from Anamirta cocculus. Phytochemistry 1999;50:1365-8.

9. Agarwal SK, Singh SS, Verma S. Antifungal principle of sesquiterpene lactones from Anamirta cocculus. Indian Drugs 1999;36:754-5.

10. Khosa RL, Prasad S. Pharmacognostical studies on Guduchi (Tinospora cordifolia Miers). J Res Ind Med 1971; 6:261-9.

11. Mehra PN, Puri HS. Studies on Gaduchi satwa. Indian J Pharm 1969;31:180-2.

12. Rao EV, Rao MV. Studies on the polysaccharide preparation (Guduchi satwa) derived from Tinospora cordifolia. Indian $J$ Pharm Sci 1981;43:103-6.

13. Chintalwar G, Jain A, Sipahimalani A, Banerji A, Sumariwalla $\mathrm{P}$, Ramakrishnan $\mathrm{R}$, et al. An immunologically active arabinogalactan from Tinospora cordifolia. Phytochemistry 1999;52:1089-94.

14. Mueller PH, Schmuelling RM, and Liebich HM, "A fully enzymatic triglyceride determination," Journal of Clinical Chemistry and Clinical Biochemistry, 15, 1977, 457-464.

15. Allain CC, Poon LS, and Chan CSG, "Enzymatic determination of total serum cholesterol," Clinical Chemistry, 20, 1974, 470-475.

16. Friedewald WT, Levy RI, and Fredrickson DS, "Estimation of the concentration of low-density lipoprotein cholesterol in 
plasma, without use of the preparative ultracentrifuge," Clinical Chemistry, 18, 1972, 499-502.

17. Adeyemi DO, Komolafe OA, Adewole SO, Obuotor EM: Anti Hyperlipidemic Activities of Annona Muricata (Linn). The Internetional Journal of Alternative Medicine. 7, 2009, DOI: 10. $5580 / 293 \mathrm{~b}$

18. Adeyemi DO, Komolafe OA, Adewole SO, Obuotor EM, Abiodun AA, Adenowo TK, Histomorphological and morphometric studies of the pancreatic islet cells of diabetic rats treated with extracts of Annona muricata. Folia Morphol. 69, No. 2, 92-100.

19.Urmila C. Kumavat, Shraddha N. Shimpi,1 and Sandesh P. Jagdale, Hypoglycemic activity of Cassia javanica Linn. In normal and streptozotocin-induced diabetic rats Journal of Advanced pharmaceutical Technology and Research, 3(1), 2012, 47-51.

20. Lehto S, Haffner SM, Pyörälä K, Kallio V, Laakso M. Dyslipidemia and hyperglycemia predict coronary heart disease events in middle-aged patients with NIDDM; Diabetes 1997; 46, 1354-1359.

21. Eisenberg DM, Kessler RC, Foster C, Norlock FE, Calkins DR,Delbanco TL Unconventional medicine in theUnited States. Prevalence, costs, and patterns of use. N Engl J Med, 328, 1993, 246-252.

22. Chattopadhyay RR A comparative evaluation of some blood sugar lowering agents of plant origin.J Ethnopharmacol, 67, 1999, 367-372.

23. Kim JD, Kang SM, Park MY, Jung TY, Choi HY, Ku SK, Ameliorative antidiabetic activity of Dangnyosoko, a Chinese herbal medicine in diabetic rats. Biosci Biotechnol Biochem, 71, 2007, 1527-1534.

24. Singh SS, Pandey SC, Srivastava S, Gupta VS, Patro B, Ghosh AC, Chemistry And Medicinal Properties Of Tinospora Cordifolia (Guduchi) Indian Journal Of Pharmacology 2003; 35: 83-91 